\title{
Retention of Sediments and Nutrients in Jackson Creek Wetland near Delavan Lake, Wisconsin, 1993-95
}

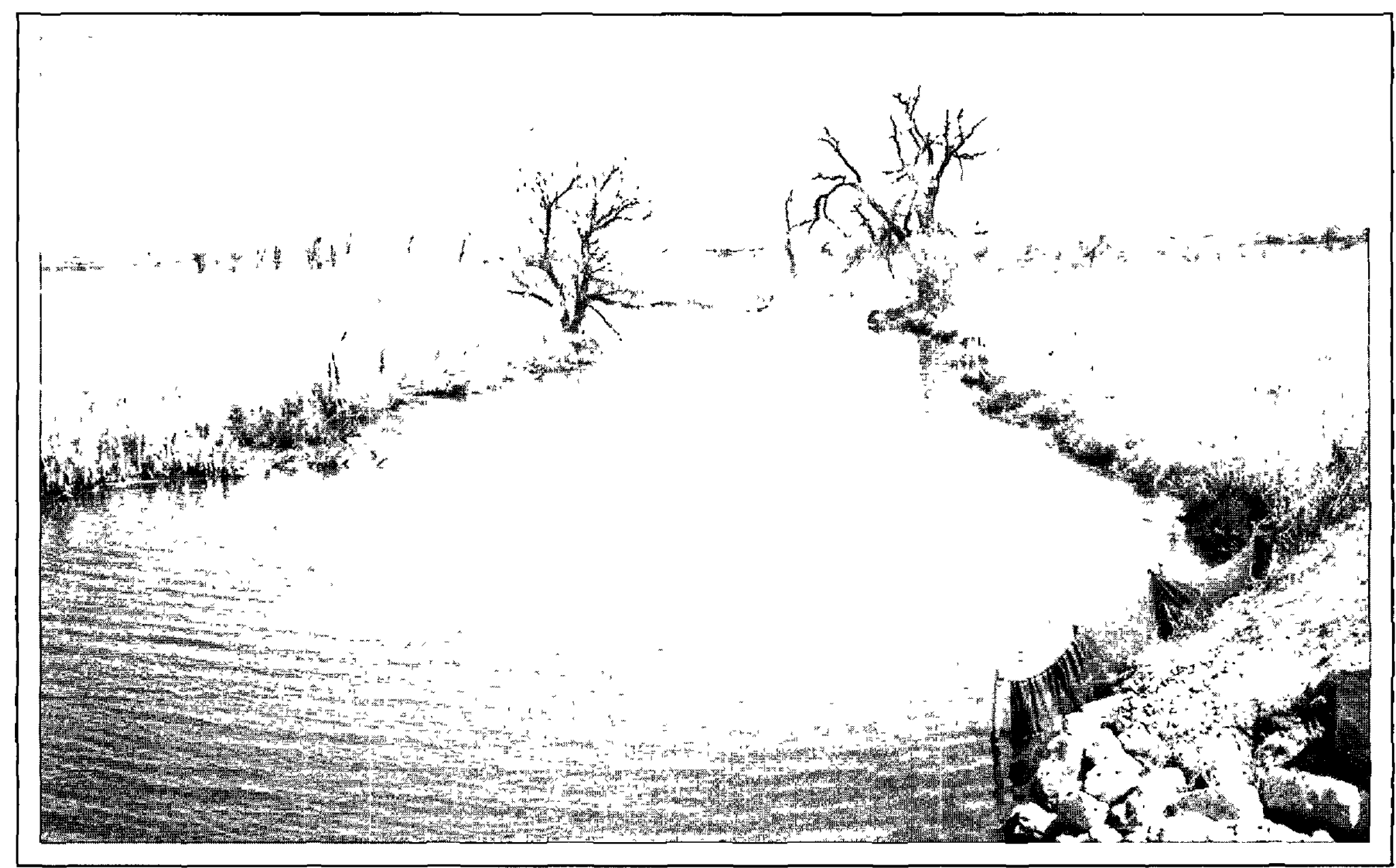

Prepared in cooperation with the TOWN OF DELAVAN, WISCONSIN

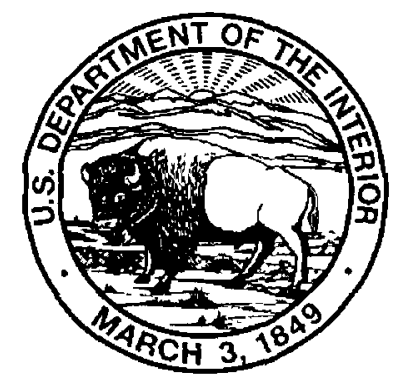




\section{RETENTION OF SEDIMENTS AND \\ NUTRIENTS IN JACKSON CREEK WETLAND \\ NEAR DELAVAN LAKE, WISCONSIN, \\ 1993-95}

By Gerald L. Goddard and John F. Elder

U.S. GEOLOGICAL SURVEY

Water-Resources Investigations Report 97-4014

Prepared in cooperation with the

TOWN OF DELAVAN, WISCONSIN

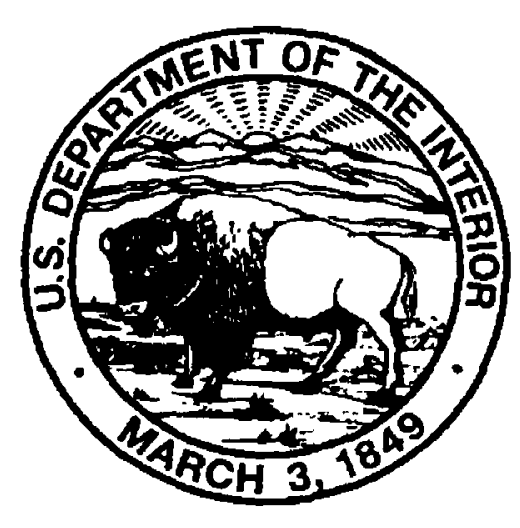

Madison, Wisconsin

1997 


\title{
U.S. DEPARTMENT OF THE INTERIOR BRUCE BABBITT, Secretary
}

\author{
U.S. GEOLOGICAL SURVEY \\ Gordon P. Eaton, Director
}

For additional information write to:

Copies of this report can be purchased from:

District Chief

U.S. Geological Survey

6417 Normandy Lane

Madison, WI 53719
U.S. Geological Survey

Branch of Information Services

Box 25286

Denver, CO 80225-0286 


\section{PREFACE}

This Water-Resources Investigation Report has been prepared in conjunction with a Fact Sheet (Elder and Goddard, 1996) to make the results of the Jackson Creek Wetland study available to the residents and users of the Delavan Lake system, cooperators on the project, our colleagues in water resources research, and the general public. Although the two reports present findings from the same study, they serve different purposes. The fact sheet provides a synopsis of the data in aggregated form, along with highlights of the interpretation of those data, and major conclusions from the study; hence it is most useful to those who seek an overview of the research and its major implications. This report is intended to provide more complete data presentation and explanation, along with additional description of the data analysis; its purpose is to serve the needs of those who require more detailed technical information. 


\section{CONTENTS}

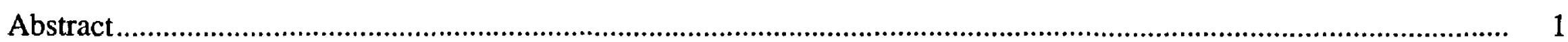

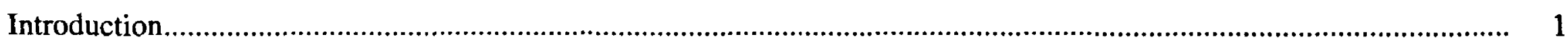

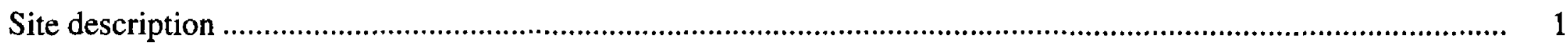

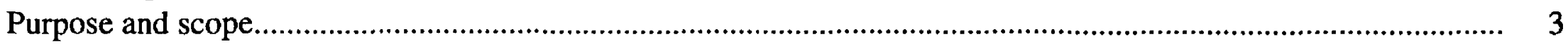

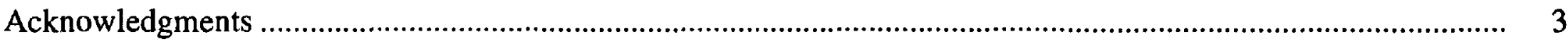

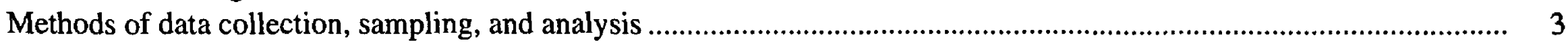

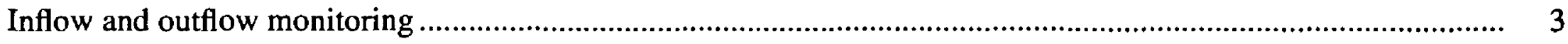

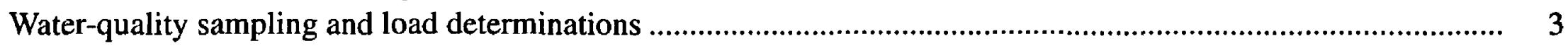

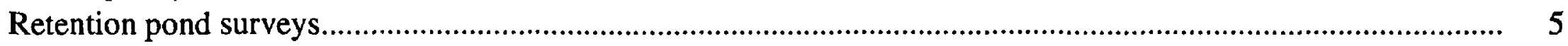

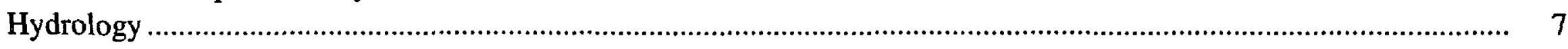

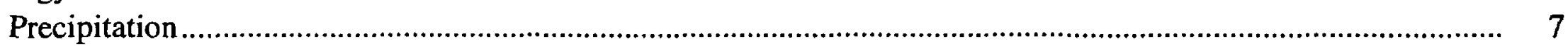

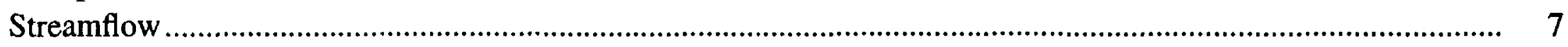

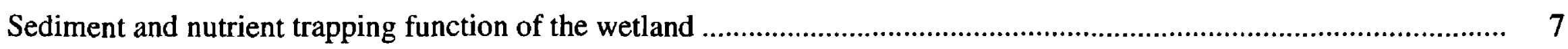

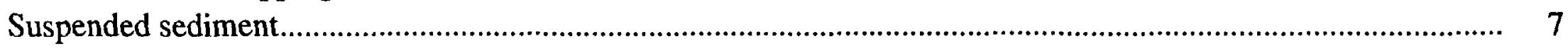

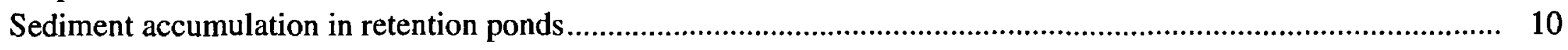

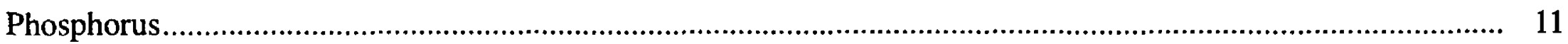

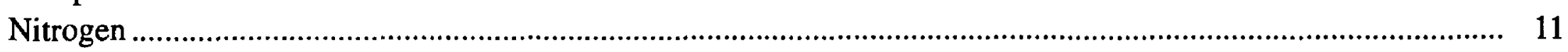

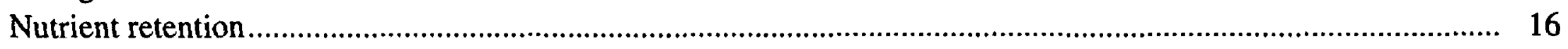

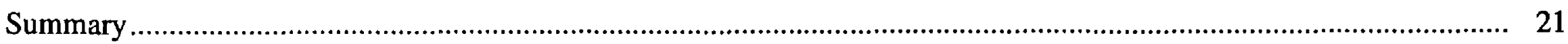

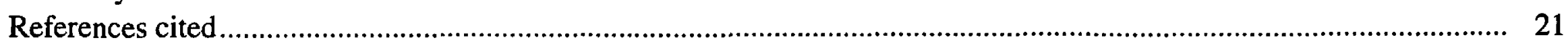

\section{FIGURES}

1. Map showing location of Delavan Lake, Jackson Creek Wetland, three inflowing streams (Jackson Creek and its tributaries), and outflow of wetland to Delavan Lake Inlet....

2. Aerial view of Jackson Creek Wetland, showing inflowing and outflowing streams and sediment retention ponds

3. Cross-section and sediment core-sample locations on north, east, and west ponds in Jackson Creek Wetland .

4A. Graphs showing average daily loads of suspended sediment and phosphorus at inflow (total of all stream inflows) and outflow of Jackson Creek Wetland, and percent difference in loads.

4B. Graphs showing average daily loads of nitrogen species at inflow (total of all stream inflows) and outflow of Jackson Creek Wetland, and percent difference in loads

5. Suspended-sediment budget for Jackson Creek Wetland, water years 1994-95 .......................................... 16

\section{TABLES}

1. Drainage areas of Jackson Creek and its tributaries

2. Summary of streamflow characteristics for Jackson Creek Wetland inflow and outflow gaging stations, water years 1993-95

3. Statistical summaries of suspended sediment and nutrient concentrations at Jackson Creek Wetland inflow and outflow gaging stations, February 1993 to September 1995

4. Summary of inflow and outflow water-quality loads at Jackson Creek Wetland, water years $1993-95$.

5. Average daily loads of suspended sediment and nutrients at inflow (total of all stream inflows) and outflow of Jackson Creek Wetland, and percent difference in loads

6. Results of cross-section surveys of north pond in Jackson Creek Wetland, 1992-95 ........................................ 17

7. Results of cross-section surveys of east pond in Jackson Creek Wetland, 1992-95 ...................................... 18

8. Results of cross-section surveys of west pond in Jackson Creek Wetland, 1993-95 ........................................ 19

9. Sediment-core bulk densities in north, east, and west ponds in Jackson Creek Wetland ................................... 20 


\section{CONVERSION FACTORS, VERTICAL DATUM, AND ABBREVIATED WATER-QUALITY UNITS}

\begin{tabular}{rll}
\hline Multiply & By & To Obtain \\
inch (in.) & 25.4 & millimeter \\
inch (in.) & 25,400 & micrometer \\
foot $(\mathrm{ft})$ & 0.3048 & meter \\
mile (mi) & 1.609 & kilometer \\
pound (lb) & 453.6 & gram \\
acre & 0.4047 & hectare \\
square mile $\left(\mathrm{mi}^{2}\right)$ & 2.590 & square kilometer \\
cubic foot $\left(\mathrm{ft}^{3}\right)$ & 0.02832 & cubic meter \\
cubic yard $\left(\mathrm{yd}^{3}\right)$ & 0.7646 & cubic meter \\
cubic meter per second \\
kilogram per square mile \\
pound per square mile $\left(\mathrm{lb} / \mathrm{mi}^{2}\right)$ & 0.02832 & gram per cubic centimeter \\
ton per cubic yard (ton/yd $\left.\mathrm{yd}^{3}\right)$ & 0.175 & \\
\hline
\end{tabular}

Sea level: In this report "sea level" refers to the National Geodetic Vertical Datum of 1929 (NGVD of 1929)-a geodetic datum derived from a general adjustment of the first-order level nets of both the United States and Canada, formerly called Sea Level Datum of 1929.

Abbreviated water-quality units used in this report: Chemical concentrations are given in metric units as milligrams per liter (mg/L). Milligrams per liter is a unit expressing concentrations of chemical constituents in solution as weight (milligrams) of solute per unit volume (liter) of water. For concentrations less than $7,000 \mathrm{mg} / \mathrm{L}$, the numerical value is the same as for concentrations in parts per million. 


\title{
Retention of Sediments and Nutrients in Jackson Creek Wetland near Delavan Lake, Wisconsin, 1993-95
}

\author{
By Gerald L. Goddard and John F. Elder
}

\section{Abstract}

Excessive inflow of sediment and nutrients has contributed to eutrophication of Delavan Lake in southeastern Wisconsin. A wetland restoration project at the mouth of the lake's principal inflowing stream system was implemented in 1992, primarily for the purpose of reducing sediment and nutrient loading to the lake. This function of the wetland system, which includes three retention ponds, was examined in a 32-month study (February 1993-September 1995) that included continuous monitoring of discharge of two inflowing streams and the wetland outflow, intermittent monitoring of discharge of a third inflowing stream, monthly and storm-runoff sampling to determine sediment and nutrient concentrations, and measurement of sediment accumulation in three constructed sediment retention ponds. Inflow and outflow loads of sediment and nutrients were computed from the discharge and concentration data.

The wetland system consistently retained suspended sediments during the study period. Volumetric surveys of the ponds showed sediment accumulation each year, and during the 32 months, 46 percent of the inflow sediment load was retained in the wetland and the retention ponds. Retention of nutrients in the wetland system, however, was of lesser magnitude and much greater seasonal variability. Over time periods of one year or more, most nutrient forms were retained in the wetland system. Nutrient retention, relative to the 32-month inflow loads was: 19 percent of total phosphorus, 11 percent of dissolved orthophosphate, 8 percent of total ammonia plus organic nitrogen, and 0.4 percent of dissolved nitrite plus nitrate nitrogen. Of the nutrient forms measured, only dissolved ammonia, whose 32-month outflow from the wetland system was 22 percent greater than inflow, showed a long-term net release from the system. However, net releases over shorter time periods were commonly observed for all nutrients, and these occurred frequently during the growing season, suggesting probable availability to algal and macrophyte communities downstream. Awareness of the variability and complexity of the nutrient-trapping function of a wetland system can help maintain realistic expectations of the benefits of wetland restoration projects and can be valuable in developing more effective management practices.

\section{INTRODUCTION}

\section{Site Description}

Delavan Lake (fig.1), a highly valued and heavily used sport fishery and recreational lake in southeastern Wisconsin, has experienced poor waterquality and nuisance algal growth during the past 15 years. A severe blue-green algal bloom occurred in the summer of 1983 despite modifications two years earlier to divert septic tank and sewage effluent out of the drainage basin of the 2,072-acre eutrophic lake.

The algal growth problems in Delavan Lake led to intensive, long-term hydrologic and water-quality studies and a detailed rehabilitation plan (University of Wisconsin, 1986). Among other recommendations, the plan called for construction of a wetland at the confluence of Jackson Creek and its two tributaries, which combine to form the principal inflow to Delavan Lake (fig.1). The purpose of this wetland was to reduce the inflow of sediment and nutrients to the lake and thus contribute to its long-term protection and maintenance. Seventy-four percent of the property owners in the Delavan Lake Sanitary District supported this management alternative. 


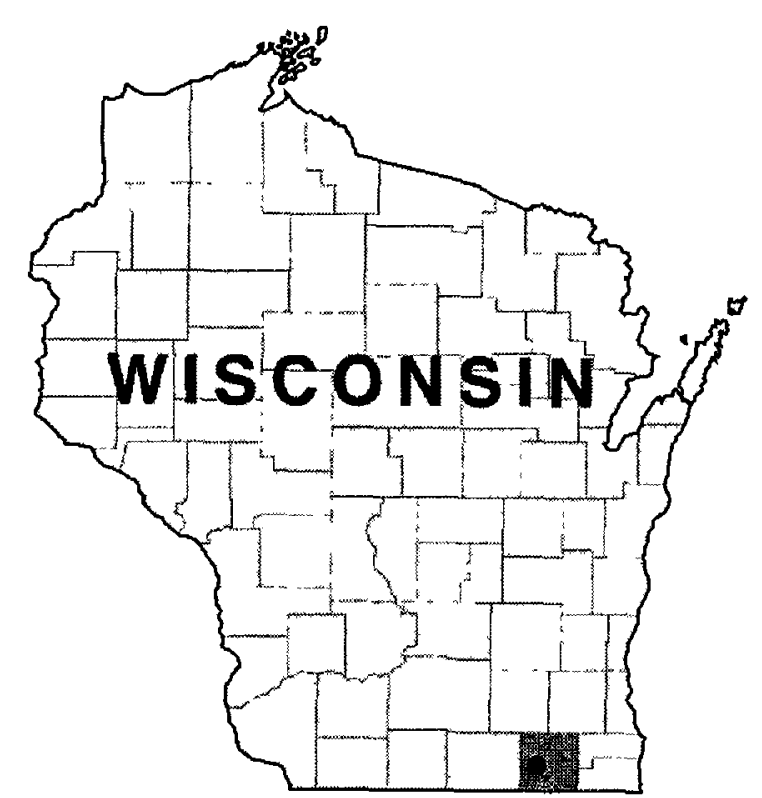

Location of study area in Walworth County
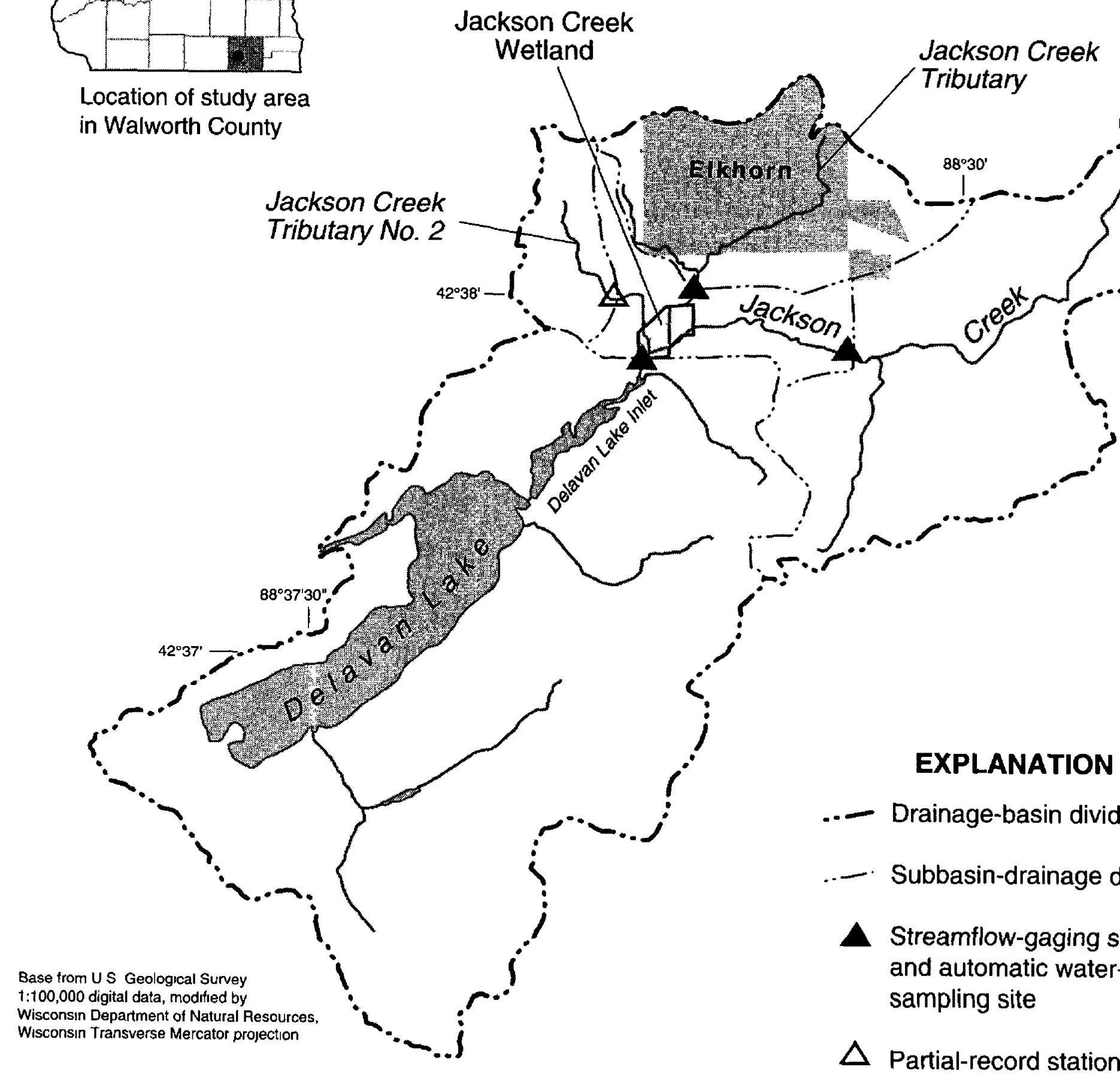
Jackson Creek Wetland was constructed in the fall of 1992 when a 15-acre wetland north of Mound Road was enlarged to 95 acres (fig. 2). The wetland was initially seeded in spring 1993 to establish the plant community. Subsequently, some areas of the wetland have been reseeded annually because the desired vegetation has not become established. Water from the wetland flows into Delavan Lake Inlet 2.0 mi upstream from Delavan Lake (fig. 1). Nearly all surface-water inflow to the wetland is from three streams-Jackson Creek, Jackson Creek Tributary, and Jackson Creek Tributary No. 2. The combined drainage area of 16.6 $\mathrm{mi}^{2}$ is used primarily for agriculture, although residential and commercial areas have been developed recently in the Jackson Creek and Jackson Creek Tributary subbasins. Details of the geology, soils, and land use are described in a previous report on Delavan Lake (Field and Duerk, 1988).

In addition to areas of sedge meadow, wet prairie, and shallow-water marsh, the wetland system contains three retention ponds along its upstream edge at the mouths of the inflowing streams (fig. 2). Jackson Creek, Jackson Creek Tributary, and Jackson Creek Tributary No. 2, respectively, flow into the east, north, and west ponds. Surface areas of these ponds are about $3.4,1.2$, and 1.2 acres, respectively. Each pond has 14 outlet swales that distribute runoff into the wetland. Access roads to the ponds were constructed around the perimeter of the wetland.

\section{Purpose and Scope}

In 1993, the U.S. Geological Survey, in cooperation with the Town of Delavan, began a study of the effectiveness of the Jackson Creek Wetland and ponds as a retention system for suspended sediment and nutrients. This report describes the design, approach, and principal findings of that study, with respect to sediment deposition in the retention ponds and nutrient inflows and outflows from the wetland during 1993 to 1995.

\section{Acknowledgments}

The authors thank personnel from the Delavan Lake Sanitary District: Kevin MacKinnon, district administrator; and Allen Hoefert, Lee Copeland, and Michell Lepkowski, who contributed to this study by checking gaging-station operations, collecting waterquality samples, and assisting with the retention-pond surveys.

\section{METHODS OF DATA COLLECTION, SAMPLING, AND ANALYSIS}

\section{Inflow and Outflow Monitoring}

Water inflow (discharge) was continuously measured upstream from the Jackson Creek Wetland at the Jackson Creek and Jackson Creek Tributary gaging stations. Inflow was also measured intermittently at a partial-record site on Jackson Creek Tributary No. 2 (fig. 1). These measurements accounted for 88 percent of the drainage area of the wetland (table 1). The remaining 12 percent of the area-the intervening areas between the gaging stations and the wetland inflow points - could not be measured because of backwater effects from the ponds. Sediment and nutrient loads from the ungaged area within each subbasin were estimated by calculating the load/drainage-area ratio for the gaged area and applying it to the ungaged area.

Outflow from the wetland was measured continuously at a weir at the gaging station on Jackson Creek at Mound Road, where water flows from the wetland into Delavan Lake Inlet.

\section{Water-Quality Sampling and Load Determinations}

Water samples for determination of suspended sediment and nutrient concentrations were collected manually at least monthly at the continuous gaging stations. These were supplemented by frequent sampling during storms by means of refrigerated, automatic water-quality samplers. Flow-integrated samples were collected at the Jackson Creek Tributary No. 2 site, by using the equal-width-increment (EWI) method described by Guy and Norman (1970). Flow-integrated and automatic sampler samples were collected simultaneously to develop coefficients to correct for concentration differences between the point samples collected by the automatic samplers and the more representative EWI samples. Samples collected for dissolved constituents were filtered through a $0.45 \mu \mathrm{m}$ filter.

Water samples were analyzed for concentrations of suspended sediment, total phosphorus, dissolved 


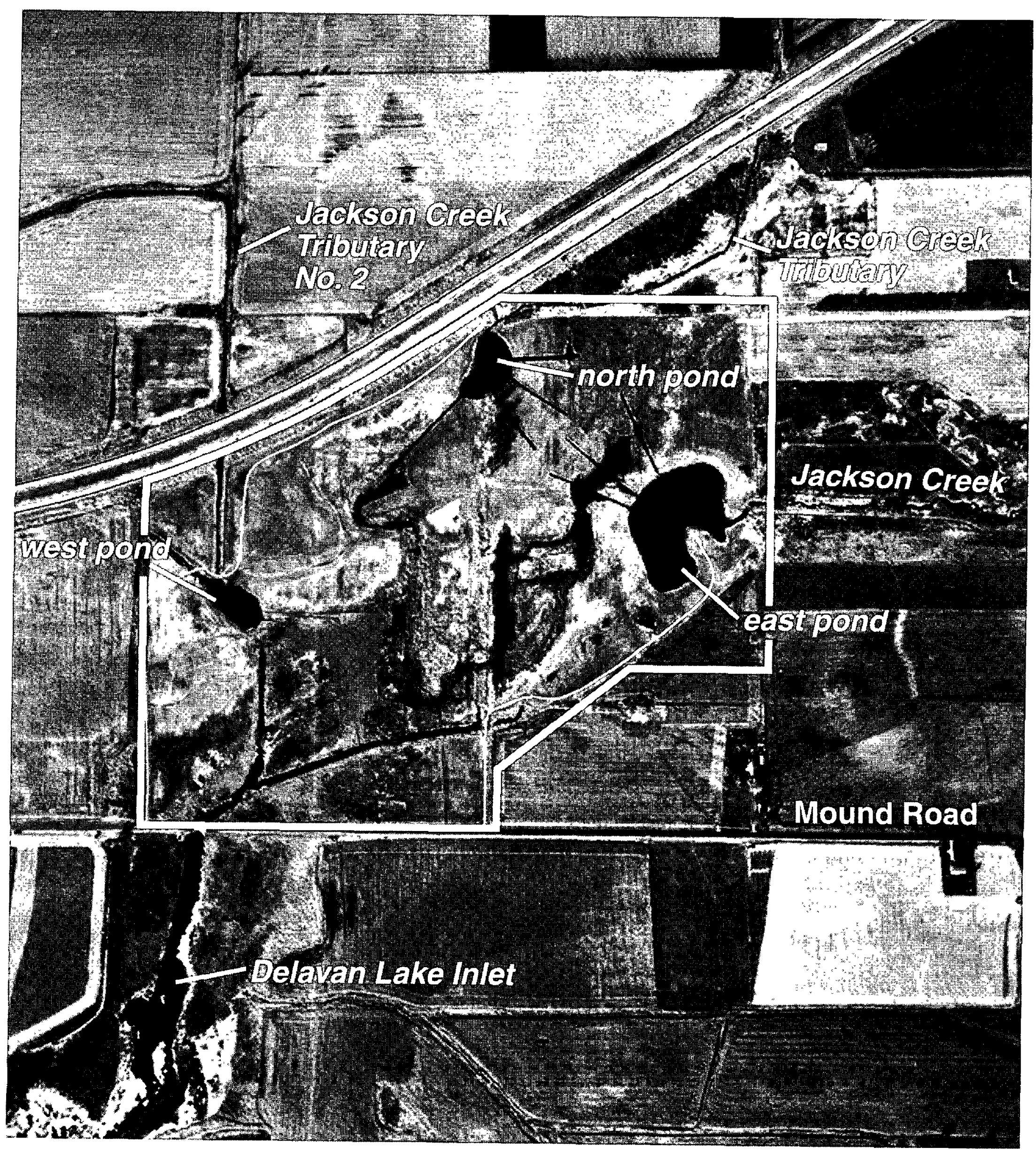

Figure 2. Aerial view of Jackson Creek Wetland, showing inflowing and outflowing streams and sediment retention ponds (photograph supplied by Rust Environmental and Infrastructure, Inc., Milwaukee, Wis.). 
Table 1. Drainage areas of Jackson Creek and its tributaries

\begin{tabular}{lcccc}
\hline & \multicolumn{3}{c}{ Drainage area, in square miles } & \\
\cline { 2 - 5 } \multicolumn{1}{c}{ Basin } & Gaged & Ungaged & Total & $\begin{array}{c}\text { Percent } \\
\text { ungaged }\end{array}$ \\
\hline Jackson Creek & 8.96 & 1.02 & 9.98 & 10.2 \\
Jackson Creek Tributary & 4.34 & .22 & 4.56 & 4.8 \\
Jackson Creek Tributary No. 2 & 1.36 & .70 & 2.06 & 34.0 \\
Total & 14.66 & 1.94 & 16.60 & 11.7 \\
\hline
\end{tabular}

orthophosphate, total ammonia plus organic nitrogen (Kjeldahl nitrogen), dissolved ammonia, and dissolved nitrite plus nitrate nitrogen. Suspended-sediment concentration analyses were performed by the U.S. Geological Survey (USGS) sediment laboratory in Iowa City, Iowa. Standard colorimetric techniques by an autoanalyzer (Fishman and Friedman, 1989) were used for determinations of the nutrient concentrations at the USGS National Water Quality Laboratory in Arvada, Colorado.

Suspended-sediment and nutrient loads were computed by use of the integration method (Porterfield, 1972) at sites for which continuous discharge data were available. For the Jackson Creek Tributary No. 2 site, loads were computed by use of a method described by Field and Graczyk (1990). The inflow load to the wetland was determined as the sum of the loads measured at the gaging stations plus the estimated load from the ungaged area. Streamflow and water-quality concentrations and loads are published in the U. S. Geological Survey annual data publications (Holmstrom and others, 1994-96).

\section{Retention Pond Surveys}

Sediment accumulation in the retention ponds was measured by annually surveying an established network of cross sections with monumented endpoints on each pond (fig. 3). Ten cross sections were established on the north and west ponds and fourteen on the east pond. Initial surveys were made in October 1992 on the north and east ponds. Four additional east pond cross sections and the west pond were initially surveyed in May 1993 because construction of these ponds was not completed until spring 1993. The elevation of the cross-section points was determined at 10- foot intervals with smaller intervals near the shoreline. Subsequently, all three ponds were surveyed in October 1993, 1994, and 1995.

The thalweg (lowest cross-section elevation point), mean water depth, and individual cross-section areas were computed by use of the Channel Geometry Analysis Program (Regan and Schaffranek, 1985). Annual pond volumes were computed at a water surface elevation of $929.00 \mathrm{ft}$ above sea level. Incremental pond volumes $\left(V_{i}\right)$ were calculated as

$$
V_{i}=\left[\left(\frac{A_{i}+A_{i+1}}{2}\right) L\right] / 27
$$

where $\mathrm{A}$ is cross-section area and $\mathrm{L}$ is distance between cross sections. Total pond volume is the sum of the incremental pond volumes. The annual sediment accumulation equalled the difference in total pond volume from year to year.

To determine bulk density of the deposited sediment, six bottom-sediment cores were collected in each pond with an acrylic gravity corer (3-in. inside diameter). The sampling location of these sediment cores is shown on figure 3.

The mass of sediment retained in the pond was calculated as the product of mean bulk density and volume of sediment accumulation. Sediment outflow from each pond was calculated as the difference between inflow and accumulation in the pond. The combined sediment outflow from the three ponds was compared to the measured wetland outflow to determine the amount of deposition in the wetland downstream from the ponds. 

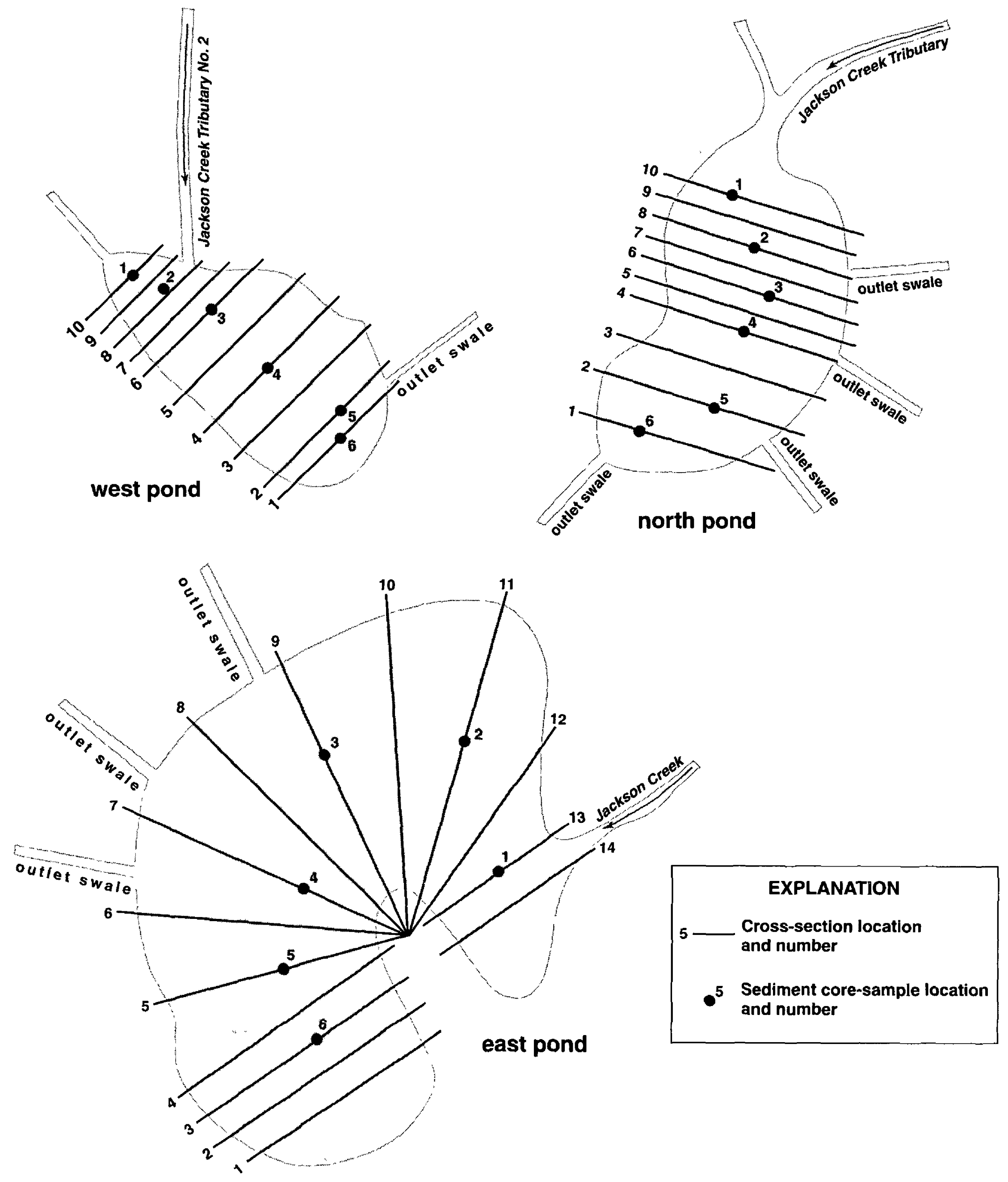

Figure 3. Cross-section and sediment core-sample locations on north, east, and west ponds in Jackson Creek Wetland. 


\section{HYDROLOGY}

\section{Precipitation}

Precipitation from February 1 to September 30, 1993 and for water years $1994-95^{1}$ at the Lake Geneva National Weather Service station (located about $6.5 \mathrm{mi}$ southeast of Jackson Creek Wetland) was 30.93, 24.72, and 32.17 in., respectively (U.S. Department of Commerce, 1993-95). Precipitation at the Burlington National Weather Service station (located about $13 \mathrm{mi}$ east-northeast of the study area) was used for December 1994 because data for that month was incomplete at the Lake Geneva station. The 1961-90 long term average precipitation for the Lake Geneva station is 36.91 in. Therefore, precipitation from February 1 to September 30,1993 was 3.59 in. above normal, while precipitation for water years 1994-95 was 12.19 and 4.74 in. below normal, respectively.

\section{Streamflow}

Streamflow characteristics for the Jackson Creek Wetland inflow and outflow gaging stations are summarized in table 2. Twelve years of record are available for Jackson Creek and Jackson Creek Tributary gaging stations. The 1993-95 annual mean discharges for Jackson Creek were 257, 63, and 66 percent, respectively, of the 12-year annual mean discharge. For Jackson Creek Tributary, the 1993-95 annual mean discharges were 182,62 , and 76 percent, respectively, of the 12-year annual mean discharge. The high discharge in 1993 was caused primarily by a major runoff event in April that had a recurrence interval of about 20 years for the Jackson Creek gage, and a recurrence interval of about 50 years at the Jackson Creek Tributary gage.

\section{SEDIMENT AND NUTRIENT TRAPPING FUNCTION OF THE WETLAND}

A statistical summary of the concentrations of suspended sediment and nutrients in water samples collected at the Jackson Creek, Jackson Creek Tributary, and Jackson Creek at Mound Road gaging stations is presented in table 3. A summary of the inflow and out-

\footnotetext{
${ }^{1} \mathrm{~A}$ water year is the 12 -month period from October 1 to September 30 . It is designated by the calendar year in which it ends.
}

flow wetland system loadings for the periods February to September 1993, water years 1994 and 1995, and the complete study period is presented in table 4 . Seasonal inflow and outflow wetland loadings are presented in table 5 and figures $4 \mathrm{~A}$ and 4B. Comparisons of inflows and outflows of suspended sediments and nutrients show the variable effectiveness of the Jackson Creek Wetland as a retention system for these constituents. More than 20 percent of suspended sediments were retained in the wetland system at all times except the winter/early spring period; during the growing season, retention was commonly greater than 80 percent. The nutrient trapping effectiveness of the wetland system was much less in terms of quantity and consistency. With the exception of dissolved ammonia, there was generally a substantial net reduction in total nutrient outflow on an annual time scale (table 4). The inflow:outflow ratio, however, was highly variable seasonally (table 5 and figs. 4A and 4B), and was frequently less than one, an indication of net release instead of retention of nutrients. The annual nutrient budget by itself thus provides incomplete information about the dynamics of nutrient transport through the system.

\section{Suspended Sediment}

During the study period from February 1, 1993 to September 30,1995, the concentrations of suspended sediment in inflow to Jackson Creek Wetland ranged from 0 to $5,750 \mathrm{mg} / \mathrm{L}$, but outflow concentrations ranged from 2 to $1,050 \mathrm{mg} / \mathrm{L}$ (table 3 ). The smaller range in outflow concentrations indicate that the heavier sediment particles were deposited in the wetland system. A total of 1,740 tons of sediment was trapped in the retention ponds and wetland, equalling a 46 percent loading reduction to the inlet and lake.

Suspended sediments were consistently retained in the wetland system (table 5 and fig. 4A), but retention varied during the year. During the two periods of the growing seasons of 1993-95 (May-June and JulySeptember), retention ranged from 23 to 86 percent, but during the nongrowing seasons (October-December and January-April), retention ranged only from 12 to 53 percent except for January-April 1994, when retention equalled 72 percent. Ninety-two percent $(800$ tons) of the 1994 water year total sediment loading to the wetland system occurred during January-April with 579 tons ( 72 percent) being trapped (fig. 4A). 


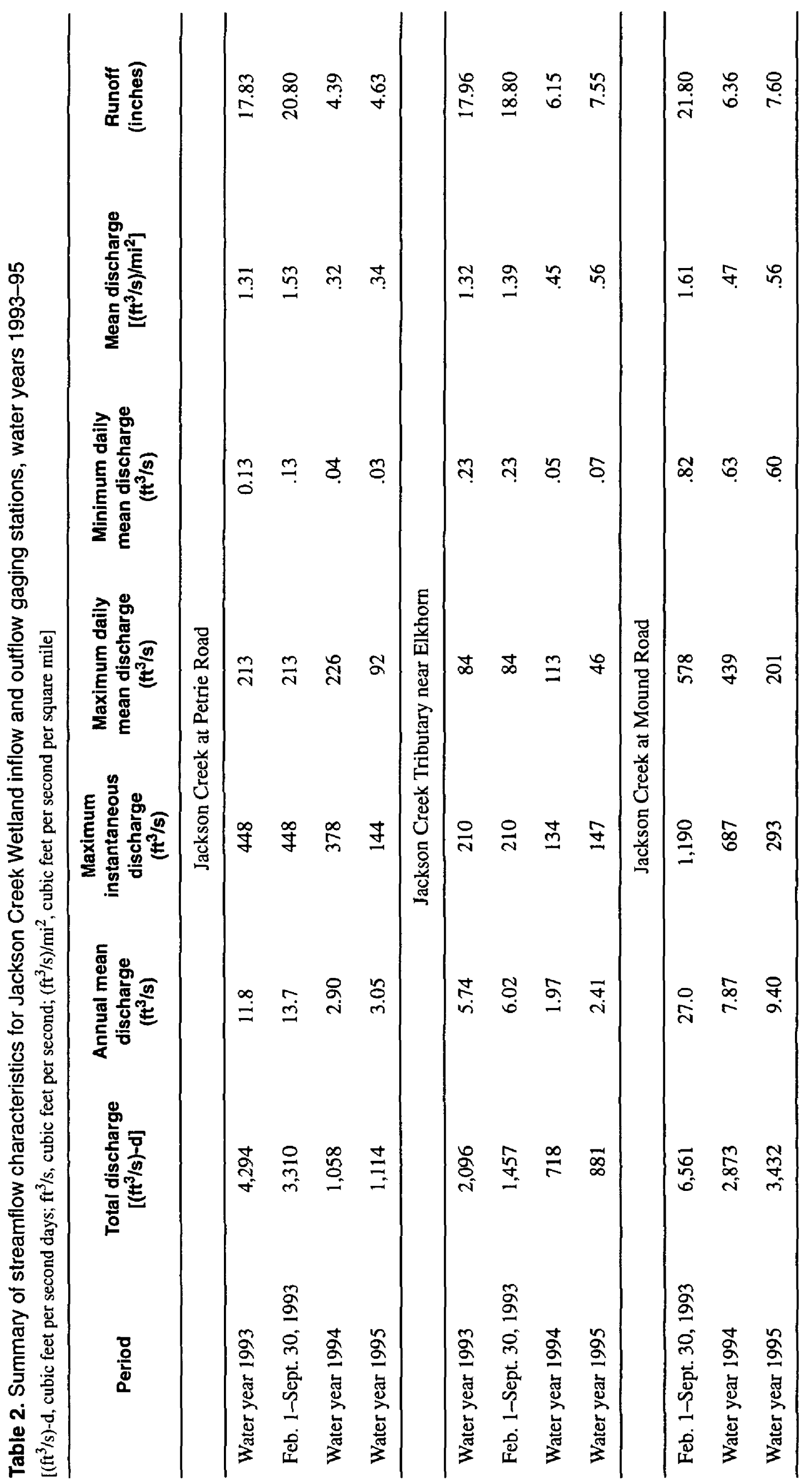


Table 3. Statistical summaries of suspended sediment and nutrient concentrations at Jackson Creek Wetland inflow and outflow gaging stations, February 1993 to September 1995 [mg/L, milligrams per liter]

\begin{tabular}{|c|c|c|c|c|c|}
\hline \multirow[b]{2}{*}{ Constituent } & \multirow[b]{2}{*}{$\begin{array}{l}\text { Number of } \\
\text { samples }\end{array}$} & \multicolumn{4}{|c|}{ Concentration, $\mathrm{mg} / \mathrm{h}$} \\
\hline & & Minimum & Maximum & Mean & Median \\
\hline \multicolumn{6}{|c|}{ Jackson Creek at Petrie Road } \\
\hline & & \multicolumn{4}{|c|}{ Feb. 1 to Sept. 30,1993} \\
\hline Suspended sediment & 200 & 3 & 5,750 & 178 & 50 \\
\hline Total phosphorus & 131 & .05 & 1.6 & .41 & .33 \\
\hline Dissolved orthophosphorus & 108 & .02 & .73 & .25 & .22 \\
\hline Total ammonia plus organic nitrogen & 108 & .50 & 6.3 & 1.85 & 1.35 \\
\hline Dissolved ammonia nitrogen & 108 & .02 & 3.6 & .40 & .17 \\
\hline \multirow[t]{2}{*}{ Dissolved nitrite plus nitrate nitrogen } & 108 & .24 & 11.0 & 4.34 & 3.95 \\
\hline & & \multicolumn{4}{|c|}{1994 water year } \\
\hline Suspended sediment & 79 & 7 & 674 & 76 & 27 \\
\hline Total phosphorus & 71 & 01 & 2.0 & .31 & .23 \\
\hline Dissolved orthophosphorus & 48 & .01 & 1.0 & .15 & .12 \\
\hline Total ammonia plus organic nitrogen & 51 & .20 & 5.8 & 1.54 & 1.3 \\
\hline Dissolved ammonia nitrogen & 49 & .03 & 2.9 & .24 & .13 \\
\hline \multirow[t]{2}{*}{ Dissolved nitrite plus nitrate nitrogen } & 49 & .05 & 14.0 & 3.83 & 3.0 \\
\hline & & \multicolumn{4}{|c|}{1995 water year } \\
\hline Suspended sediment & 225 & 0 & 661 & 45 & 18 \\
\hline Total phosphorus & 141 & .01 & 1.0 & .18 & .11 \\
\hline Dissolved orthophosphorus & 112 & $<.01$ & .58 & .10 & .05 \\
\hline Total ammonia plus organic nitrogen & 114 & .20 & 2.7 & .94 & .75 \\
\hline Dissolved ammonia nitrogen & 114 & $<.015$ & .60 & .06 & .02 \\
\hline Dissolved nitrite plus nitrate nitrogen & 114 & .05 & 15.0 & 7.23 & 7.2 \\
\hline \multicolumn{6}{|c|}{ Jackson Creek Tributary } \\
\hline & & \multicolumn{4}{|c|}{ Feb.1 to Sept. 30, 1993} \\
\hline Suspended sediment & 252 & 7 & 1,660 & 173 & 62 \\
\hline Total phosphorus & 174 & .05 & 3.6 & .37 & .24 \\
\hline Dissolved orthophosphorus & 128 & .03 & .81 & .17 & .14 \\
\hline Total ammonia plus organic nitrogen & 128 & .40 & 9.1 & 1.35 & 1.05 \\
\hline Dissolved ammonia nitrogen & 128 & .08 & .95 & .27 & .20 \\
\hline \multirow[t]{2}{*}{ Dissolved nitrite plus nitrate nitrogen } & 128 & .37 & 7.3 & 2.89 & 2.4 \\
\hline & & \multicolumn{4}{|c|}{1994 water year } \\
\hline Suspended sediment & 162 & 2 & 4,300 & 187 & 57 \\
\hline Total phosphorus & 121 & .02 & 1.9 & .33 & .21 \\
\hline Dissolved orthophosphorus & 87 & .01 & .25 & .09 & .07 \\
\hline Total ammonia plus organic nitrogen & 98 & .30 & 7.5 & 1.43 & 1.1 \\
\hline Dissolved ammonia nitrogen & 91 & .05 & 1.0 & .26 & .19 \\
\hline \multirow[t]{2}{*}{ Dissolved nitrite plus nitrate nitrogen } & 91 & .32 & 6.2 & 1.8 & 1.5 \\
\hline & & \multicolumn{4}{|c|}{1995 water year } \\
\hline Suspended sediment & 317 & 1 & 3,220 & 146 & 41 \\
\hline Total phosphorus & 215 & .01 & 3.3 & .27 & .14 \\
\hline Dissolved orthophosphorus & 179 & $<.01$ & .30 & .06 & .04 \\
\hline Total ammonia plus organic nitrogen & 180 & .2 & 6.5 & 1.1 & .75 \\
\hline Dissolved ammonia nitrogen & 179 & $<.015$ & .66 & .12 & .08 \\
\hline Dissolved nitrite plus nitrate nitrogen & 179 & .05 & 7.6 & 2.6 & 2.0 \\
\hline
\end{tabular}


Table 3. Statistical summaries of suspended sediment and nutrient concentrations at Jackson Creek Wetland inflow and outflow gaging stations, February 1993 to September 1995- - Continued

\begin{tabular}{|c|c|c|c|c|c|}
\hline \multirow[b]{2}{*}{ Constituent } & \multirow[b]{2}{*}{$\begin{array}{c}\text { Number of } \\
\text { samples }\end{array}$} & \multicolumn{4}{|c|}{ Concentration, mg/L } \\
\hline & & Minimum & Maximum & Mean & Median \\
\hline \multicolumn{6}{|c|}{ Jackson Creek at Mound Road } \\
\hline & & \multicolumn{4}{|c|}{ Feb.1 to Sept. 30,1993} \\
\hline Suspended sediment & 186 & 2 & 1,050 & 70 & 24 \\
\hline Total phosphorus & 144 & .05 & 1.2 & .27 & .21 \\
\hline Dissolved orthophosphorus & 120 & 01 & .46 & .15 & .14 \\
\hline Total ammonia plus organic nitrogen & 105 & .50 & 4.60 & 1.4 & 1.1 \\
\hline Dissolved ammonia nitrogen & 105 & .02 & 1.7 & .26 & .11 \\
\hline \multirow[t]{2}{*}{ Dissolved nitrite plus nitrate nitrogen } & 105 & .05 & 9.2 & 3.3 & 3 \\
\hline & & \multicolumn{4}{|c|}{1994 water year } \\
\hline Suspended sediment & 130 & 3 & 174 & 25 & 11 \\
\hline Total phosphorus & 119 & .02 & .92 & .27 & .24 \\
\hline Dissolved orthophosphorus & 89 & .01 & .58 & .12 & .10 \\
\hline Total ammonia plus organic nitrogen & 76 & .40 & 3.2 & 1.1 & 1.1 \\
\hline Dissolved ammonia nitrogen & 76 & .01 & .69 & .14 & .08 \\
\hline \multirow[t]{2}{*}{ Dissolved nitrite plus nitrate nitrogen } & 76 & $<.05$ & 7.4 & 1.5 & .50 \\
\hline & & \multicolumn{4}{|c|}{1995 water year } \\
\hline Suspended sediment & 230 & 2 & 163 & 26 & 18 \\
\hline Total phosphorus & 168 & .02 & .47 & .13 & .09 \\
\hline Dissolved orthophosphorus & 153 & $<.0 \mathrm{I}$ & .22 & .05 & .02 \\
\hline Total ammonia plus organic nitrogen & 149 & .40 & 2.1 & .80 & .80 \\
\hline Dissolved ammonia nitrogen & 149 & $<.015$ & .46 & .06 & .02 \\
\hline Dissolved nitrite plus nitrate nitrogen & 149 & $<.05$ & 13.0 & 3.9 & 3.1 \\
\hline
\end{tabular}

These percentages show the importance of considering seasonal variations when evaluating the transport of constituents through the wetland system. During the 32month study period, trapping efficiency equalled 74 percent during the growing season (May-September), but only 34 percent during the nongrowing season (October-April), probably because of the effect of greater vegetation density during the growing season.

A suspended-sediment budget for the Jackson Creek Wetland for water years 1994-95 is summarized in figure 5. The west, north, and east ponds retained 34 , 47 , and 74 percent of sediment inflow, respectively. The 2-year combined retention of 752 tons ( 58 percent of inflow) leaves an estimated total sediment outflow from the ponds of 536 tons. Nearly all this amount ( 532 tons) was measured at the wetland outlet at Mound Road. The residual 4 tons of sediment was presumably trapped in the wetland between the ponds and Mound Road. This assumption is supported by the observed sediment deposition in the channel upstream from the weir at Mound Road.

\section{Sediment Accumulation in Retention Ponds}

Results from the four cross-section surveys of the ponds are presented in tables $6-8$. The north and east pond cross-section properties and pond volumes are for the 3-year period October 1992 to October 1995. Four of the east pond cross sections could not be surveyed, however, until May 1993. Assuming some sediment was deposited in these cross-section locations from October 1992 to May 1993, the computed change in volume of the east pond may be slightly low. The west pond crosssection properties and volumes are for the period from late May 1993 to October 1995. Data from these and subsequent surveys can be used to determine when dredging of the ponds is required to maintain their sediment-trapping effectiveness.

Sediment accumulated in the ponds each year with total accumulations for the three ponds ranging from 310 to $2,048 \mathrm{yd}^{3}$ during the study period. In the north and west ponds, most sediment was deposited at the downstream ends of the ponds. In the north pond, 60 
percent of the sediment was deposited between cross sections 1 to 4 , and in the west pond, 89 percent of the deposition occurred between cross sections 1 to 6 . In the east pond, however, 58 percent of the deposition was at the upstream end, between cross sections 9 to 14 . This was probably due to the larger size (compared to the north and west ponds) and noncircular shape of the pond, in addition to redirection of most of the flow through the three outlet swales near the middle of the pond. During the study period, $2.1 \mathrm{ft}$ of deposition was measured at cross-section no. 13. The average thalweg elevation change from 1992 to 1995 was $0.5 \mathrm{ft}$ for the north and east ponds and $0.2 \mathrm{ft}$ from 1993 to 1995 for the west pond.

Mean bulk densities of the deposited sediment in the north and east ponds are similar -0.49 and 0.50 ton/yd ${ }^{3}(0.58-0.60$ grams per cubic centimeter) respectively (table 9). By contrast, the mean sediment bulk density in the west pond was only $0.29 \mathrm{ton} / \mathrm{yd}^{3}(0.35$ $\mathrm{gm} / \mathrm{cm}^{3}$ ). The feeder stream to the west pond, Jackson Creek Tributary No. 2, is predominantly a wide, lowgradient channel, inhabited by abundant attached vegetation. Such an environment favors settling of dense sediment particles in the channel before they can reach the pond.

\section{Phosphorus}

Maximum observed concentrations of total phosphorus and dissolved orthophosphate were about 67 and 42 percent less, respectively, at the wetland outlet than at the inflow stations. Total phosphorus inflow concentrations ranged from 0.01 to $3.60 \mathrm{mg} / \mathrm{L}$, but outflow concentrations ranged only from 0.02 to 1.20 $\mathrm{mg} / \mathrm{L}$. Similarly, inflow dissolved orthophosphate concentrations ranged from $<0.01$ to $1.00 \mathrm{mg} / \mathrm{L}$, but outflow concentrations ranged only from $<0.01$ to 0.58 $\mathrm{mg} / \mathrm{L}$ (table 3).

Comparison of inflow and outflow loads showed that total phosphorus and dissolved orthophosphate were retained in the wetland each year (table 4). During the periods of February-September 1993 and water years 1994-95, the retention of total phosphorus was 9, 39 , and 12 percent, respectively. In the same periods, the retention of dissolved orthophosphate was 10,12 , and 13 percent. However, these annual mass balance totals are somewhat misleading. Examination of the monthly differences between of inflow and outflow loads reveals that most retention occurred during the winter high-flow periods. For some months of the year, especially during spring and summer, the wetland system actually exported more phosphorus than was imported to it.

An example of the seasonal variability of phosphorus mass balance can be seen in the 1994 water-year data (table 5 and fig. 4A). The season of greatest transport during that year was, by far, the winter/early spring period. That period was also the time of greatest fractional retention of total and dissolved phosphorus. This combination of high transport and retention accounted for nearly all of the annual net retention; it overshadowed later small-volume releases during low-flow periods. In fact, virtually all retention in water year 1994 occurred in February. Net retention was nearly zero from October through January, but all other months were actually periods of net phosphorus release, shown by the large positive differences during the third and fourth periods. Increased phosphorus mobilization during spring and summer might be due to anaerobic conditions caused by higher rates of microbial respiration during warmer temperatures (Mitsch and Gosselink, 1993). Anaerobic conditions were also the probable cause of the fish kills observed in the channels and ponds of the wetland.

\section{Nitrogen}

Inflow concentrations of total ammonia plus organic nitrogen during the study period ranged from 0.20 to $9.10 \mathrm{mg} / \mathrm{L}$, while outflow concentrations ranged from 0.40 to $4.60 \mathrm{mg} / \mathrm{L}$ (table 3 ). Total ammonia plus organic nitrogen was retained in the wetland system from February 1993 to June 1994 except for the October-December period when a relatively small load of about $378 \mathrm{lb}$ was released. From June 1994 to September 1995, total ammonia and organic nitrogen was consistently released from the wetland system (fig. 4B).

Inflow and outflow dissolved ammonia nitrogen concentrations ranged from $<0.015$ to $3.60 \mathrm{mg} / \mathrm{L}$ and from $<0.015$ to $1.70 \mathrm{mg} / \mathrm{L}$, respectively, during the study (table 3). Dissolved ammonia was generally retained in the wetland system during the growing seasons of water years 1993-94 except for July-September 1994 when the inflow/outflow loads were nearly equal. It was released from the wetland system during the fall to early spring (nongrowing) periods. There was also release from the wetland system during 9 of 12 months in water year 1995. 


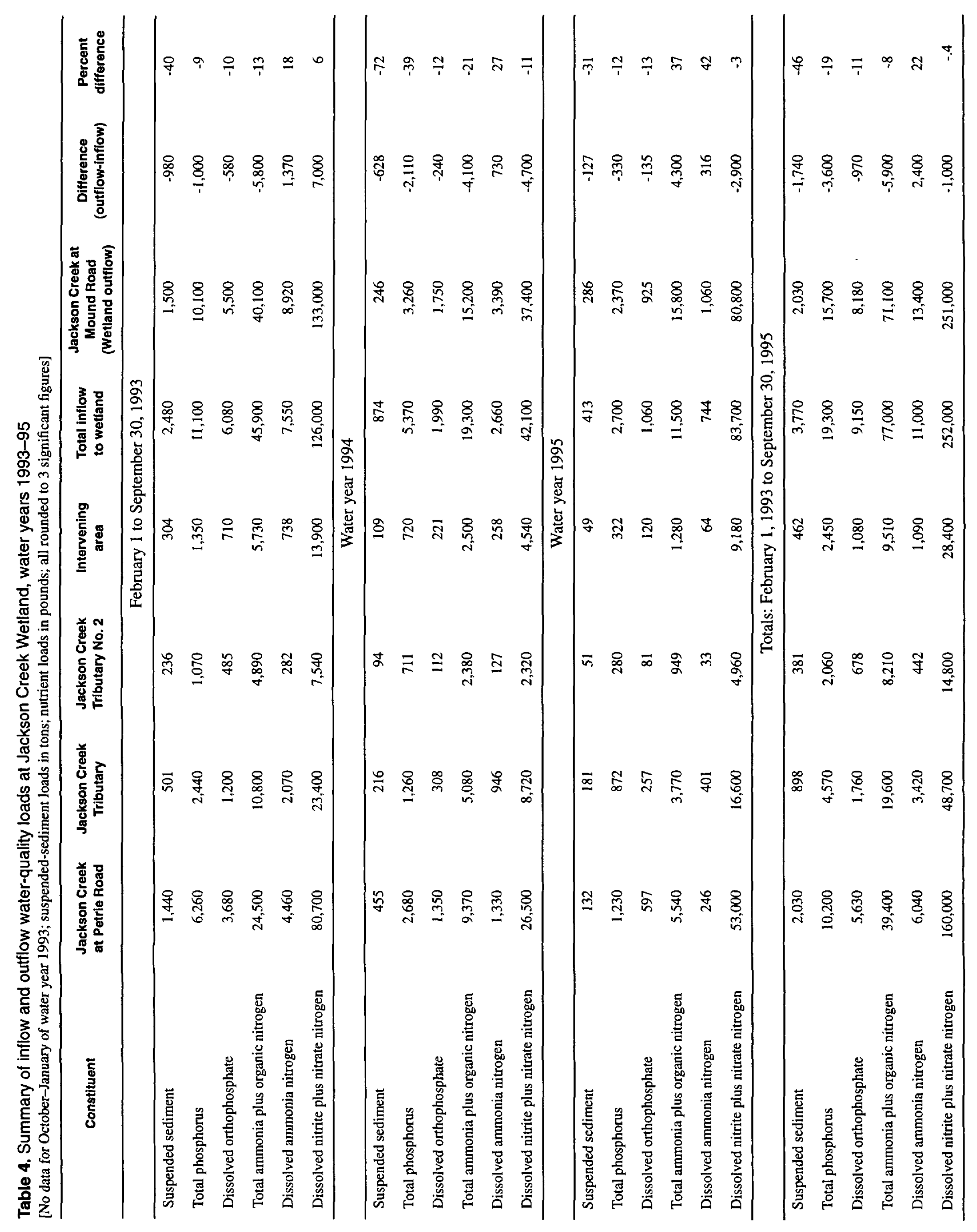




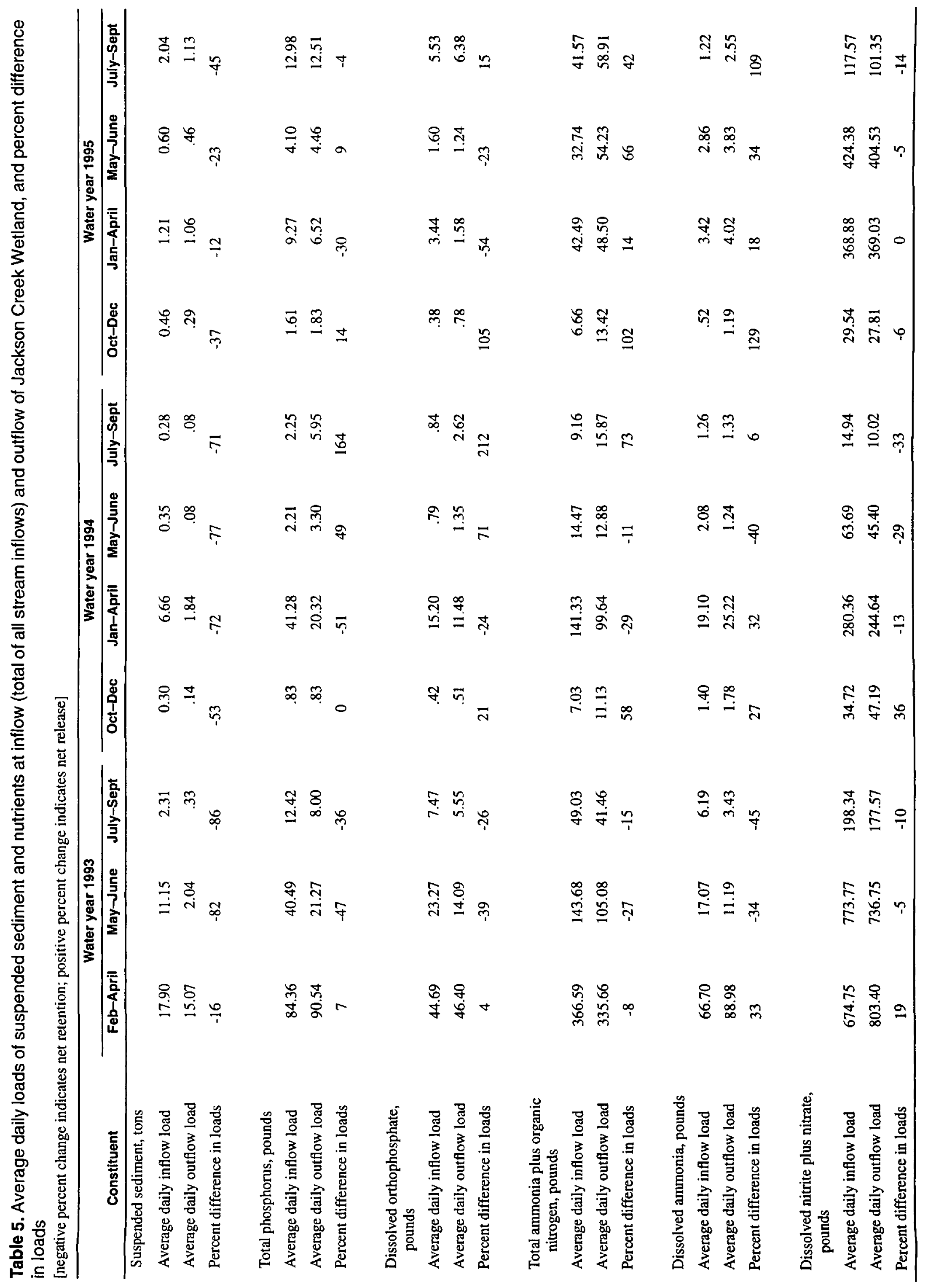




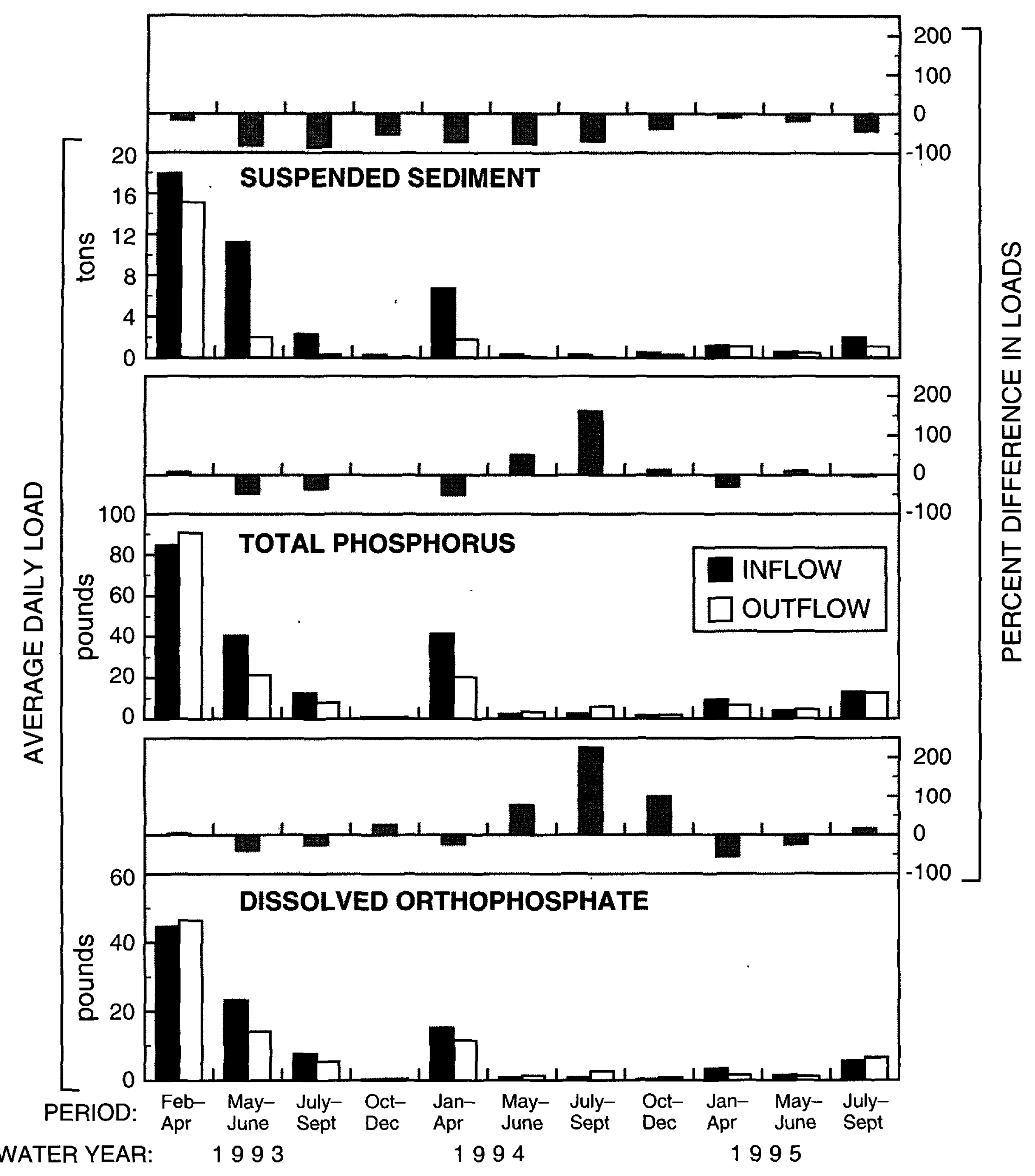

Figure 4A. Average daily loads of suspended sediment and phosphorus at inflow (total of all stream inflows) and outflow of Jackson Creek Wetland, and percent difference in loads. Negative percent change indicates net retention; positive percent change indicates net release. 


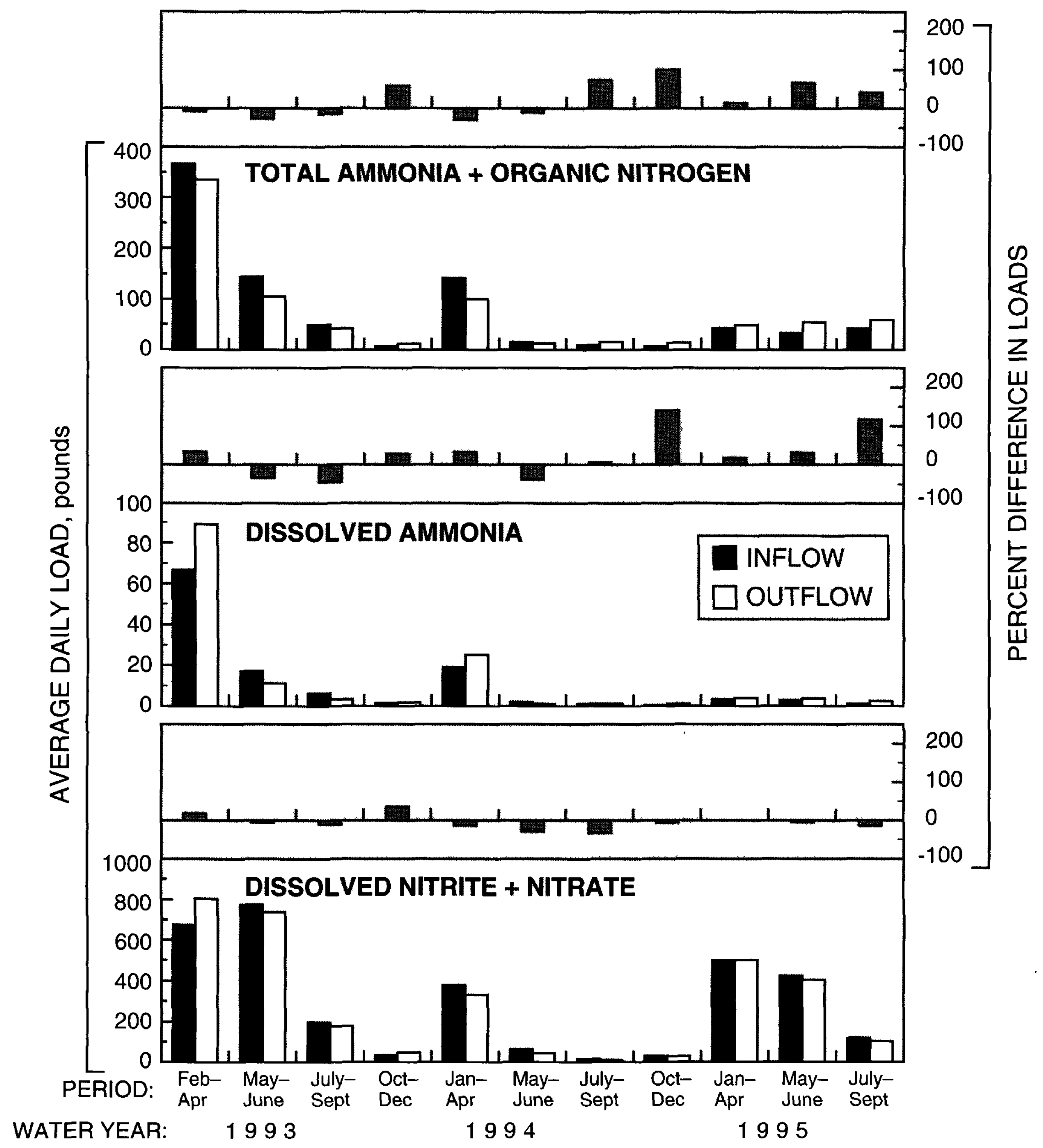

Figure 4B. Average daily loads of nitrogen species at inflow (total of all stream inflows) and outflow of Jackson Creek Wetland, and percent difference in loads. Negative percent change indicates net retention; positive percent change indicates net release. 


\begin{tabular}{|c|c|c|c|}
\hline Stream & $\begin{array}{l}\text { Jackson Creek } \\
\text { Tributary No. } 2\end{array}$ & $\begin{array}{c}\text { Jackson Creek } \\
\text { Tributary }\end{array}$ & Jackson Creek \\
\hline Total pond sediment inflow, tons & 219 & 417 & 652 \\
\hline Pond & & roc & $x<0$ \\
\hline Sediment accumulation, $\mathrm{yd}^{3}$ & 254 & 396 & 968 \\
\hline Mean bulk density, ton/yd ${ }^{3}$ & $\times 0.29$ & $\times 0.49$ & $\times 0.50$ \\
\hline Sediment trapped in pond, tons & $=74$ & $=194$ & $=484$ \\
\hline Pond sediment ouflow, tons & 145 & 223 & 168 \\
\hline Total pond sediment outflow, tons & & 1 & \\
\hline Additional wetland deposition, tons & & 4 & \\
\hline Sediment ouflow at Mound Road, ton & & 532 & \\
\hline
\end{tabular}

Figure 5. Suspended-sediment budget for Jackson Creek Wetland, water years $1994-95$ (yd $^{3}=\mathrm{cubic}_{\mathrm{c}}$ yards; ton/yd $\mathrm{d}^{3}=$ tons per cubic yard).

The inflow and outflow dissolved nitrite plus nitrate nitrogen concentrations were nearly equal. This constituent varied over a diurnal cycle that was inversely related to discharge: it was generally at its highest concentration during low flow, and decreased as flow increased, presumably because of dilution effects. A pattern of seasonal variation also existed in which concentrations were at their lowest during the summer; gradually increased through the fall, winter, and early spring to their highest level; and then decreased again during the growing season. This was probably related to the seasonal variation of uptake by aquatic biota.

Dissolved nitrite plus nitrate was retained in the wetland system on a seasonal basis throughout the study period except for the February-April and October-December periods of 1993 (fig. 4B). These two periods of release from the wetland system practically nullified the retention in all the other periods. Overall, from February 1993 to September 1995, inflow and outflow loadings were nearly equal. However, in water years 1994-95 retention was noted during the growing seasons, presumably because of uptake by wetland vegetation, and most release occurred during the nongrowing seasons.

\section{Nutrient Retention}

The Jackson Creek Wetland apparently is not continuously effective as a site for nutrient retention, even in its current status as a relatively young and highly productive aquatic system. This finding, although illustrating some limitation of the wetland system as a nutrient sink, does not necessarily conflict with the general concept of nutrient retention in wet- 


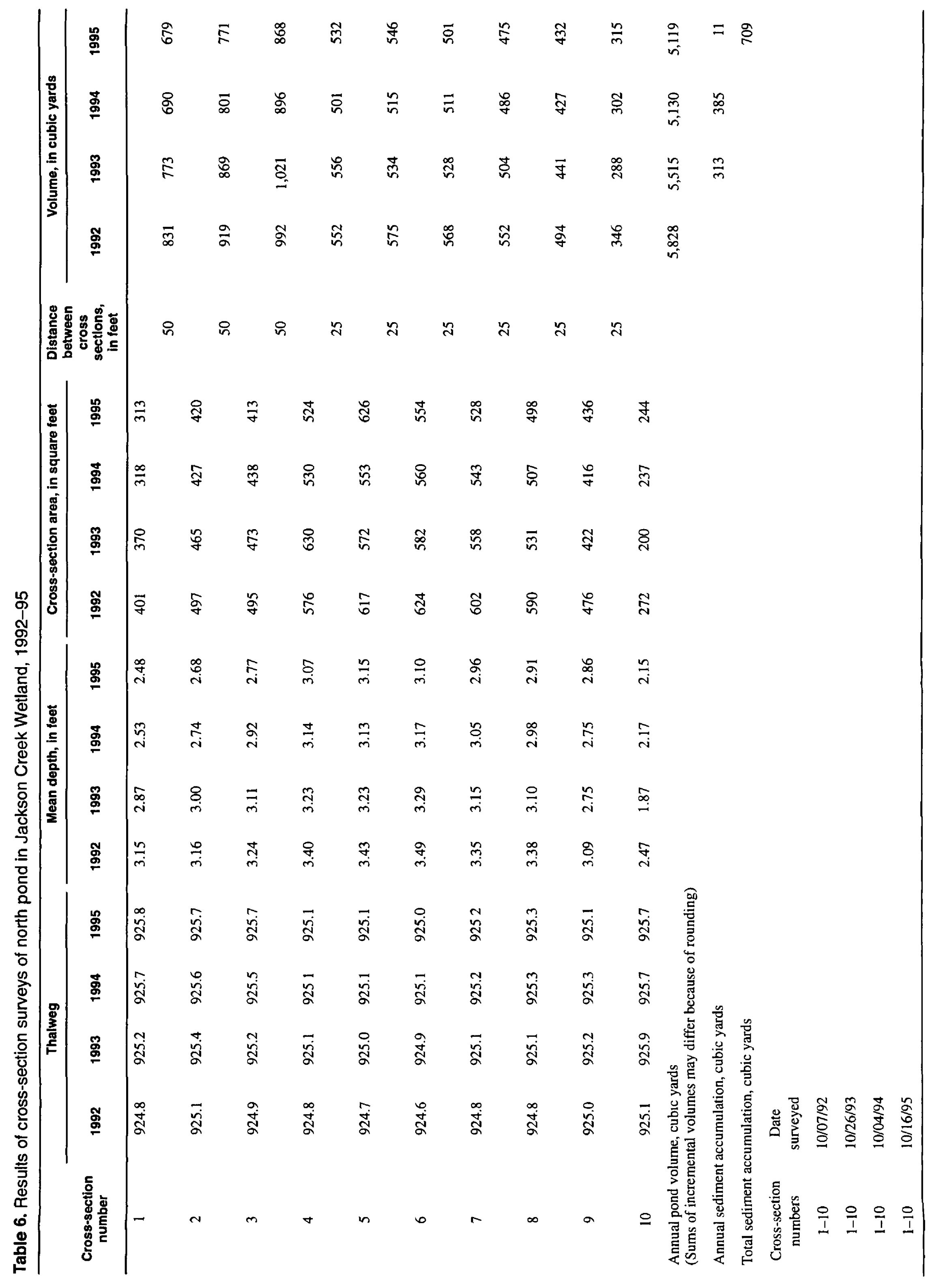




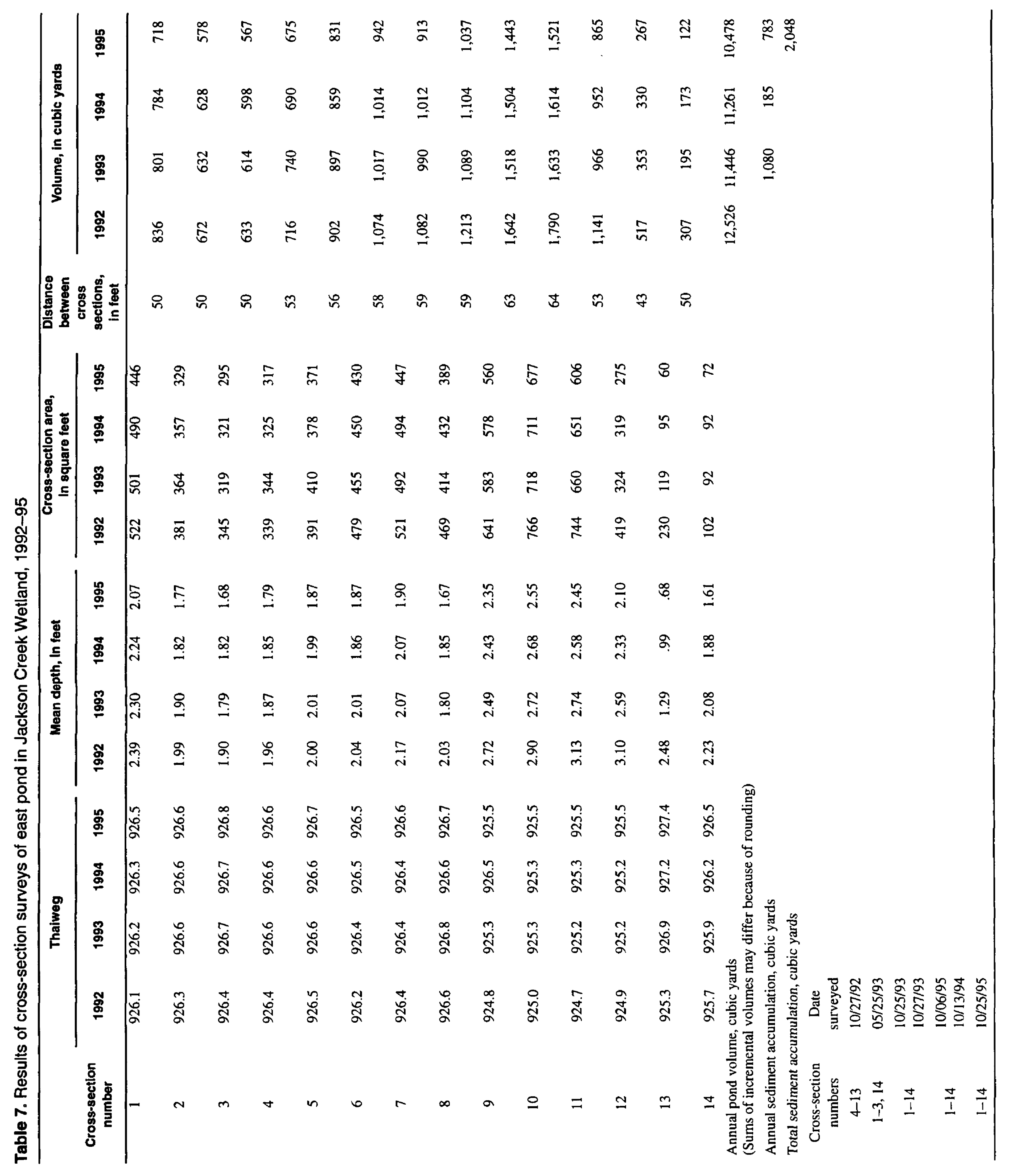




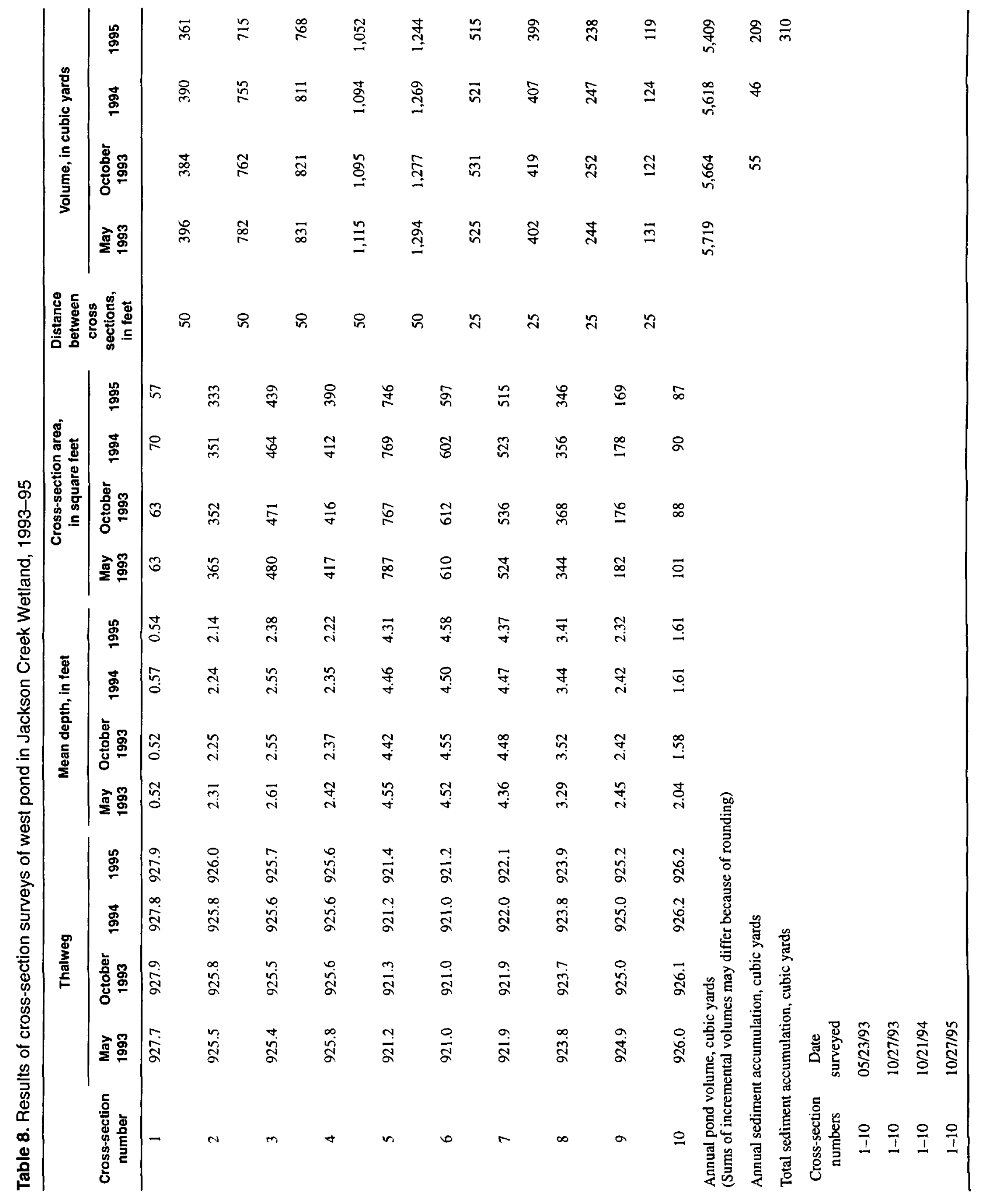


Table 9. Sediment-core bulk densities in north, east, and west ponds in Jackson Creek Wetland

$\left[\mathrm{g} / \mathrm{cm}^{3}\right.$, grams per cubic centimeter; ton $/ \mathrm{yd}^{3}$, tons per cubic yard]

\begin{tabular}{|c|c|c|}
\hline \multirow[b]{2}{*}{ Sediment core no. } & \multicolumn{2}{|c|}{$\begin{array}{l}\text { Sediment-core } \\
\text { bulk density }\end{array}$} \\
\hline & $\mathrm{g} / \mathrm{cm}^{3}$ & ton $/ y d^{3}$ \\
\hline \multicolumn{3}{|c|}{ North Pond } \\
\hline NP1 & 0.57 & 0.48 \\
\hline NP2 & .48 & .39 \\
\hline NP3 & .67 & .55 \\
\hline NP4 & .58 & .50 \\
\hline NP5 & .58 & .49 \\
\hline NP6 & .60 & .52 \\
\hline Mean & .58 & .49 \\
\hline \multicolumn{3}{|c|}{ East Pond } \\
\hline EP1 & .81 & .66 \\
\hline EP2 & .54 & .45 \\
\hline EP3 & .52 & .43 \\
\hline EP4 & .53 & .43 \\
\hline EP5 & .40 & .35 \\
\hline EP6 & .79 & .68 \\
\hline Mean & .60 & .50 \\
\hline \multicolumn{3}{|c|}{ West Pond } \\
\hline WP1 & .30 & .25 \\
\hline WP2 & .33 & .28 \\
\hline WP3 & .24 & .21 \\
\hline WP4 & .27 & .23 \\
\hline WP5 & .27 & .23 \\
\hline WP6 & .66 & .55 \\
\hline Mean & .35 & .29 \\
\hline
\end{tabular}

lands. As observed in other wetlands (Elder, 1988; Richardson, 1988), the temporal variability in retention reflects the capacity of the system to function not only as a sink but also, periodically, as a facilitator of nutrient transformation and release. Phosphorus releases tended to occur in the late spring and early summer, coincident with the likely timing of algal blooms in the downstream Delavan Lake Inlet and Delavan Lake. Also, the proportional release of dissolved orthophosphate-the fraction that is readily available for algal uptake-was even greater than that of total phosphorus during these periods. The effect of these phosphorus releases on algal growth is unknown.
The lack of coupling between suspended sediment and nutrient dynamics is also notable. Presumably, suspended material is retained in the wetland because of the reduced velocity of water flow, which allows the material to settle. We might expect that the nutrient loads would be largely associated with oxidized suspended sediments and, therefore, would be entrained in the wetland system together with the sediments. However, this was clearly not the case at Jackson Creek Wetland; net release of nutrients often coincided with substantial retention of sediments. This result suggests that biogeochemical processes mobilized the sediment-associated nutrients and thus prevented their effective retention in the wetland system, at least periodically. Even though nutrient releases were 
measured, the wetland system did reduce total loadings (except for dissolved ammonia) to Delavan Lake.

Precipitation and runoff are additional factors that influenced the 1993-95 nutrient load characteristics. The high water flows in 1993 produced heavy nutrient loading into and out of the wetland system, evident in the results given in table 4 and figures $4 \mathrm{~A}$ and $4 \mathrm{~B}$. The abnormally high flow volumes and velocities that year may have also reduced the nutrient retention effectiveness of the wetland system as indicated by the relatively low net retention amounts in 1993. Vegetation that acts to decrease water velocities and promote deposition of sediment (and associated nutrients) in the wetland was also at a minimum during this period.

The study period was not of sufficient length to observe any trends in the sediment and nutrient trapping effectiveness of the wetland system. Some areas were also replowed and reseeded several times during the study period, and thus the plant growth was not uniform throughout the wetland.

\section{SUMMARY}

A hydrologic and water quality study of the Jackson Creek Wetland from February 1993 to September 1995 showed that sediment was consistently retained in the retention ponds and the wetland, but nutrient trapping efficiency was much more variable. During the study period, about 1,740 tons of suspended sediment (46 percent of the inflow load) was retained in the wetland system. Nearly all of this sediment accumulated in the three retention ponds. Volumetric surveys of the three ponds measured sediment accumulation each year. The north and east ponds, respectively, trapped 708 and 2,048 $\mathrm{yd}^{3}$ of sediment from October 1993 to September 1995, while the west pond trapped $310 \mathrm{yd}^{3}$ from May 1993 to September 1995. During water years 1994-95, about 58 percent of the total suspended-sediment inflow load to the wetland system was trapped in the ponds. Seasonal variations in sediment trapping efficiency were also noted. Trapping efficiency during the growing season (May-September) equalled 74 percent, but only equalled 34 percent during the nongrowing season (October-April) during the study period.

For February-September 1993 and water years 1994-95, total phosphorus loads were reduced by 9 , 39 , and 12 percent for a total retention of about 3,600 lb. Even though total phosphorus was retained on an annual basis, seasonal releases from the wetland sys- tem were important. In water year 1994, nearly all total phosphorus retention occurred in February. None was retained in October-December, and a total release of $750 \mathrm{lb}$ occurred in May-September, a critical period for algal growth in Delavan Lake. Dissolved orthophosphate retention averaged about 11 percent each year, but also showed significant seasonal releases.

Total ammonia plus organic nitrogen was generally retained in the wetland system from February 1993 to June 1994 except for a release of about $380 \mathrm{lb}$ in October-December 1993. After June 1994, it was consistently released from the wetland system. Dissolved ammonia was also released from the wetland system during most of the study period. Retention did occur during May-September 1993 and May-June 1994 but during the entire study period, outflow of dissolved ammonia was about 22 percent more than inflow. The wetland system appeared to have little net effect on dissolved nitrite plus nitrate. Nearly equal amounts were retained during the growing seasons as were released during the nongrowing seasons. However, even though the dissolved ammonia loadings increased through the wetland system and seasonal releases of the other nutrients were measured, the Jackson Creek Wetland did reduce overall annual loadings of sediment and the other nutrients to Delavan Lake during the study period. Trapping efficiency of the ponds and the wetland was the greatest for sediment, total phosphorus, and dissolved orthophosphate.

The results of this study illustrate the complexities of biogeochemical cycles in ecosystems, wetlands included. A better understanding of these complexities may help us to avoid placing unrealistic expectations on natural or constructed wetlands for reducing nutrient loadings in areas with similar climate and runoff conditions.

\section{REFERENCES CITED}

Elder, J.F., 1988, Factors affecting wetland retention of nutrients, metals, and organic materials, in Kusler, J.A., and Brooks, G., eds., Wetland Hydrology: Chicago, Ill., Association of State Wetland Managers, Inc., p. 178184.

Elder, J.F., and Goddard, G.L., 1996, Sediment and nutrient trapping efficiency of a constructed wetland near Delavan Lake, Wisconsin, 1993-95: U.S. Geological Survey Fact-Sheet FS-232-96, 4 p.

Field, S.J., and Duerk, M.D., 1988, Hydrology and water quality of Delavan Lake in southeastern Wisconsin: 
U.S. Geological Survey Water-Resources Investigations Report 87-4168, 61 p.

Field, S.J., and Graczyk, D.J., 1990, Hydrology, aquatic macrophytes, and water quality of Black Earth Creek and its tributaries, Dane County, Wisconsin, 1985-86: U.S. Geological Survey Water-Resources Investigations Report 89-4089, 38 p.

Fishman, M.J., and Friedman, L.C., eds., 1989. Methods for determination of inorganic substances in water and fluvial sediments: U.S. Geological Survey Techniques of Water-Resources Investigations, book 5 , chap. A1, $545 \mathrm{p}$.

Guy, H.P., and Norman, V.W., 1970, Field methods for measurement of fluvial sediment: U.S. Geological Survey Techniques of Water-Resources Investigations, book 3 , chap. C2, 59 p.

Holmstrom, B.K., Kammerer, P.A., Jr., and Ellefson, B.R., 1994, Water resources data, Wisconsin, water year 1993: U.S. Geological Survey Water-Data Report WI93-1, $707 \mathrm{p}$.

1995, Water resources data, Wisconsin, water year 1994: U.S. Geological Survey Water-Data Report WI94-1, 645 p.

1996, Water resources data, Wisconsin, water year 1995: U.S. Geological Survey Water-Data Report WI95-1, 562 p.
Mitsch, W.J., and Gosselink, J.G., 1993, Wetlands: New York, Van Nostrand Reinhold, (2nd Ed.), 722 p.

Porterfield, G., 1972, Computation of fluvial sediment discharge: U.S. Geological Survey Techniques of WaterResources Investigations, book 3, chap. C3, 66 p.

Regan, R.S., and Schaffranek, R., 1985, A computer program for analyzing channel geometry: U.S. Geological Survey Water-Resources Investigations Report 854335, 49 p.

Richardson, C.J., 1988, Freshwater wetlands: transformers, filters, or sinks?: Forem (Duke University), v. 11, p. 3-9.

U.S. Department of Commerce, 1993, Climatological data annual summary: National Oceanographic and Atmospheric Administration. v. 98, no. 13, 26 p.

U.S. Department of Commerce, 1994, Climatological data annual summary: National Oceanographic and Atmospheric Administration. v. 99, no. 13, 26. p.

U.S. Department of Commerce, 1995, Climatological data annual summary: National Oceanographic and Atmospheric Administration. v. 100, no. 13, 26. p.

University of Wisconsin, Institute for Environmental Studies, 1986, Delavan Lake: a recovery and management study: $332 \mathrm{p}$. 
